
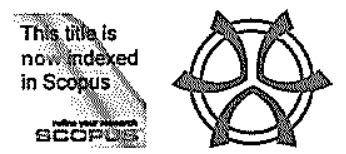

\title{
CITY DEVELOPMENT STRATEGIES (CDS) CONTRIBUTION TOWARD SUSTAINABLE URBAN DEVELOPMENT IN DEVELOPING COUNTRIES
}

\author{
S. Mostafa Rasoolimanesh' \\ School of Housing, Building and Planning, \\ UNIVERSITI SAINS MALAYSIA \\ Nurwati Badarulzaman ${ }^{2}$ and \\ School of Housing, Building and Planning, \\ UNIVERSITI SAINS MALAYSIA \\ Mastura Jaafar ${ }^{3}$ \\ School of Housing, Building and Planning, \\ UNIVERSITI SAINS MALAYSIA
}

\begin{abstract}
Today one of the important concerns of cities is growth by sustainable development. However sustainable urban development has been used in various forms and explained by various definitions, this subject is accompanied by uncertainty. New approaches in urban planning have attempted to achieve sustainable development. One of these is City Development Strategies (CDS), a new strategic planning approach that has been employed in more than 200 cities worldwide to achieve sustainable growth. However, CDS achieve different levels of success in sustainability. This paper takes the initiative to investigate the contribution of CDS toward sustainable urban development by looking for inclusion of principle of sustainable urban development in CDS themes. However CDS themes are various such as sustainable urban development definitions, therefore this inclusion is different. This paper highlights this relationship and inclusion for one the latest definition of CDS presented by Cities Alliance in 2006. This definition can succeed to achieve sustainability on some aspects, especially environmental and economic sustainability and fail to achieve some ones. This output is discussed in relation to CDS themes that have been applied in developing countries.
\end{abstract}

Keywords: city development strategies, CDS, sustainable urban development, urban planning, developing countries, Cities Alliance.

\footnotetext{
'S. Mostafa Rasoolimanesh is a PhD candidate. School of Housing, Building and Planning,Universiti Sains Malaysia, Pulau Pinang, Malaysia. email: rasooli1352@yahoo.com

${ }^{2}$ Senior Lecturer, School of Housing, Building and Planning,Universiti Sains Malaysia, Pulau Pinang, Malaysia.

${ }^{3}$ Lecturer, School of Housing, Building and Planning,Universiti Sains Malaysia, Pulau Pinang, Malaysia.
} 


\section{INTRODUCTION}

Developed, developing and transitional cities around the world during the past several decades have coped with global changes in the economy, institutional structures, civil society, and the environment. Nevertheless, these changes have had a significant impact on urban areas (UN-Habitat 2009). The changes in economic and institutional structures in civil society in the form and scale of environmental- and conflict-related challenges have had strongly-felt effects on urban development and socio-spatial dynamics in urban areas. As a result, the cities are in the middle of dealing with the impact of three major trends: i) globalization, ii) decentralization of responsibilities, and iii) rapid population growth (Cities Alliance 2005).

Urban planning is a tool for use in addressing the unprecedented challenges facing 21 st-century cities and in promoting sustainable urban development (UN- Habitat 2009. Sustainable urban development requires that a balance be reached between economic, environmental, and social necessities. In order to achieve a balance, Local Agenda 21 (LA21) was proposed at the United Nations Conference on Environment and Development (UNCED) in 1992. LA21 is "an agenda that puts forward a vision and sets tasks in order to promote sustainable development at the local level and shows a menu of action" (Nakaguchi 2004, p. 28 cited by Tonami \& Mori 2007).

Urban planning is presently regarded as a tool that attempts to convert the impact of change to priorities for the enhancement of sustainable urban development with a focus on investment and the upgrading of urban areas, infrastructure and land-use regulation (UN-Habitat 2009). Planning is currently regarded as a strategic, rather than a comprehensive, activity. Planning also highlights a developmental movement from the past to the future. The vision of the future is not a simple matter of shortterm political agenda practicality. It is expected to be able to bring about long term improvements in infrastructure, environment and quality of life. City Development Strategies (CDS) is a strategic planning approach that is supported by the work of Michael Porter on urban competitiveness (1995). CDS are more responsive to the World Bank's economic development priorities (Cities Alliance 2000) to achieve sustainable development. Until 2009, more than 200 CDS had been established and applied in different cities around the world with varying degrees of success (Keivani 2009). City Development Strategies focused through comprehensive action plans for improved urban governance, financial responsibility and the establishment of clearly articulated priorities for action and investment (Mukhija 2006). CDS is a process that is undertaken by its local stakeholders to create a vision for their city through a participatory process. It seeks to address the global changes that affect the urban area and enhance urban sustainability. The objective of this paper is to conduct a study to investigate the contribution of CDS in sustainable urban development with a focus on the inclusion of principles of urban sustainable development in CDS themes. 
PLANNING MALAYSIA

Journal of the Malaysian Institute of Plamers (2011)

\section{THE CONCEPTS AND PRINCIPLES OF SUSTAINABLE URBAN DEVELOPMENT (SUD)}

In an effort to define sustainable urban development (SUD), many concepts and definitions have been created. The terms urban sustainability and sustainable city apply to the appropriate conditions, such as the proper use of resources, protection of the natural environment, least possible use of non-renewable resources, economic growth and variety, community self-confidence, individual welfare, and satisfaction of basic human needs (Shen et al. 2010). According to the United Nations Sustainable Cities Program, a sustainable city has continuing access to natural resources on which its development depends. A sustainable city maintains a stable security from environmental adventures that may threaten development achievements (Whitehead 2003). According to Whitehead (2003), "it is asserted that the sustainable city represents an economic space within which the social, economic and ecological contradictions of capitalism are being managed and strategically addressed". Sustainable urbanization and sustainable urban development apply to a dynamic process towards suitable conditions, that in this process are focused on environmental, economic, social and governance sustainability as an equal concern (Shen et al. 2010).

Sustainable development needs a balance between economic, environmental, and social necessities. According to LA21, sustainability has four dimensions. They are social, economic, environmental and institutional aspects (Spangenberg, Pfahl \& Deller 2002).

In order to build a sustainable urbanization, cities should develop their social and economic structures without damaging their natural environment and, instead, achieve the right balance between humans and the natural resources (Abu-Ghazalah 2008). Achieving this balance can take place with a system that combines personal opinion, which can be provided by the participation of citizens in this process, and scientific knowledge, which can be provided by scientific analysis (Jepson 2001 as cited in Roy 2009). In such a system, sustainable urban development can become a new vision that will serve to guide the planning agenda for the twenty-first century" (Beatley 1995; Beatley \& Manning 1997; Berke \& Conroy 2000; Berke 2002; Campbell 1996; Jepson $2004 \mathrm{~b}$ as cited in Saha \& Paterson 2008).

According to the survey by Saha \& Petarson (2008), in which they reviewed Protney (2003), Jepson (2004) and Conroy (2006), four aspects of SUD have been defined. These four studies specifically looked at sustainable activities to evaluate the plans of local governments and cities for sustainable development. Therefore, we consider it to be suitable for our purpose. Because there are many definitions and indicators of SUD, 
this particular set of activities and principles is used to assess cities and their plans to achieve sustainability. We can also use it to evaluate CDS as a strategic plan that is adopted to ensure sustainability.

Saha \& Petarson emphasize three aspects - environment, economic and social. We also took into consideration in this paper the governance aspect of Convey (2006) that was cited in Saha \& Petarson (2008) (Table 1).

\section{URBAN PLANNING AS A TOOL TO ACHIEVE SUSTAINABLE URBAN DEVELOPMENT}

Urban planning is a traditional tool for achieving a balance among competing interests. It can also be an important tool for promoting interaction among planners, officials and the local community (Diamantini \& Zanon 2000). Thus, urban planning can play a key role in achieving sustainable urban development. The goal of sustainable urban development is to reach a balance among the disparate interests of four groups economic, environmental, social and govemance - in order to have livable, productive and inclusive cities, towns and villages (UN-Habitat 2009). City planning leads to the evaluation of the social, economic, and environmental impacts of urban policies. It allows for a systematic analysis of the relationship between social, economic, and environmental developments. This permits a description of the mutual dependence of city planning and sustainable development at the strategic and operational level (Rotmansa, Asselta \& Vellingab 2000).

Consequently, urban planning has a key role in promoting future urban and regional sustainability and a response to the global changes and major trends that affect cities, especially those in the developing world. Strategic urban planning systems have developed over the last decade(s). They often consist of a framework that is linked to a set of indicators, so that the sustainability of city policies can be evaluated (Rotmansa, Asselta \& Vellingab 2000).

City Development Strategies (CDS) is an urban strategic planning approach, which was initiated in East Asia by the World Bank in 1998 to attain sustainability of growth in cities.

\section{CITY DEVELOPMENT STRATEGIES (CDS) IN DEVELOPING COUNTRIES}

\section{Concepts and definitions}

CDS is a process planned by the local stakeholders to formulate a vision for their city through a participatory process. This involves viewing and conducting an analysis 
of the city's perspectives for development, recognizing priorities for investment and development, and implementing a vision through partnership-based approaches. It is, therefore, both a process and content to promote competitiveness, livability, management, and bankability of the respective city (Kyung-Hwan, 2002). Nonetheless, CDS processes in developing cities differ from those for developed cities, and therefore require different strategic responses. In addition, conditions in developing cities differ from those of very poor cities in Sub-Saharan Africa; those of cities that have transitional-economies, such as Prague and Sofia; and those of soon-to-be-rich cities, such as Chengdu, China (Cities Alliance 2006b).

Developed cities use CDS to promote their competitiveness, livability, and so on. Actually, developed cities have a long history of strategic planning to achieve their goals. Although the real content of CDS differs enormously between developed and developing cities, there has never been any intrinsic reason why we cannot exchange the technical processes and products adopted in developed countries for the experience in financial innovation of developing countries. Similarly, there is no intrinsic reason to prevent the exchange of comparative urban experiences or knowledge resources to be used by developing cities (Cities Alliance 2006b).

As mentioned earlier, the city development strategies approach draws significantly from Michael Porter's work that suggests that economic development strategies should be based on the competitive advantages of cities and regions and should have a more active role for the private sector, and a less involved role for governments. Many scholars disagree and argue that governments are likely to have a more involved role in successful economic development (Fainstein \& Gray 1995; Goldsmith 1995, as cited in Mukhija 2006). Other critics also suggest that governments need to play a more active role to ensure that the jobs that are created are better jobs with higher wages (Schweke, 1995, as cited in Mukhija, 2006).

In order to face a competitive and unpredictable economic environment, the developing world needs to implement some effective measures to use their restricted financial and human resources to achieve the intended objectives. The capital available to any city is very elastic and only flows to cities that plan their future and can attract and keep it. An effective CDS process can both attract capital and use it effectively (Cities Alliance 2006a).

City Development Strategies provide a methodology for mayors, private sectors, and citizens to develop a sustainable vision for their cities and a strategy to achieve it. However, comprehensive approaches to connect the environmental sustainability to economic growth, poverty reduction, and the other urban challenges are not yet typical of many CDS (Cities Alliance 2006b). 
However, based on Cities Alliance (2006a), there is a second trend involving the CDS process in developing countries. It is an increasing focus on enhancing a city's competitiveness, with the aim of empowering and achieving more economic growth. Experience has shown that complete understanding of local economic conditions, and an ability to identify a city's competitive advantages, is an essential basis for the development of effective strategies to enhance economic resurgence (Cities Alliance 2007).

\section{CDS themes in developing countries}

CDS takes many forms, depending on the location, context and players. However, in the CDS manual, Cities Alliance (2002) in China explained that:

The process is one of preparing a long-term vision of the city's future, from which is drawn a short-term action plan. The focus of a CDS is not only on strengthening economic competitiveness. Poverty reduction, environmental, urban structure, infrastructure, and financial aspects are also covered. The process is participative, involving major stakeholders from all segments of society. The product is a development strategy that is designed to evolve as implementation proceeds and the city's competitive position changes.

There are perhaps five defining characteristics:

- The CDS process and product is owned by the city

- A CDS takes a long-term view, but concludes with an action plan;

- There is significant participation of stakeholders in the process,

- The conclusion is strategic and multi discipline in nature;

- The process drives new methods of thinking about the city's development and its

- sustainability

- The establishment of a sustainable vision for the city and a CDS must be the basis of sustainable development in urban management (Cities Alliance, 2006a).

Until 2009, more than 200 CDS had been established and applied in different cities around the world with varying degrees of success (Keivani 2009). It must be noted however, that a CDS process needs to be local, so that each city has its own CDS in themes and methodology (Cities Alliance 2009). In other words, the foundation of CDS in different cities is not the same as with one another. Nevertheless, in order to assess the CDS, the guideline defined by the Cities Alliance (2006b) is adopted in this paper. This guideline states, "the CDSs should sustainably enhance urban performance, measured in terms of: (i) economic growth, linked to improved livelihood opportunities; (ii) poverty prevention and alleviation; and (iii) improved environmental and public health, inclusive of poor and informal urban communities". 
According to this guideline, CDS has five substantive themes which are expressed in the following and their elements have been presented in Table 2 .

The five important CDS themes are:

\section{- Livelihood}

Livelihood covers three areas: (i) the business climate and capacity to create smallbusinesses. The business climate is very different in cities, which attempt to attract investment in a diversity of business climates and set aside a suitable business area in which to establish small businesses and business networks (ii) urban competitiveness. A CDS should determine a comparative and competitive advantage that creates an economic cluster in order to attract investors and achieve economic growth; and (iii) human resource development, which has a key role in preventing or relieving poverty. It fulfills its role by accessing training, and the quality thereof.

\section{- Environmental sustainability}

Environmental sustainability in the CDS process can be defined in three areas: (i) environmental quality, such as air \& water quality, which are very important in environmental sustainability; (ii) service delivery including geographical coverage, accessibility and affordability should be sustainable, especially in developing countries. It should be noted that these concerns are very significant; and (iii) energy efficiency that affects the welfare of residents.

\section{- Spatial form and its infrastructure}

Urban economic competitiveness cannot be achieved and the welfare of city residents cannot be taken care of without the required infrastructures. Additionally, spatial form has a key role in urban congestion, energy efficiency accessibility and distribution of services. Therefore, it can be essential in poverty reduction.

\section{- Financial resources}

The financial analysis of a city determines how finance resources should be used to implement the infrastructures, and public facilities, etc. Financial analysis predicts and provides conditions necessary to attract private sector funding, issuing bonds, and financial innovation. Revenue diversity and increasing this, as well as the control of expenditures, and cash-flow management and, in summary, financial planning and budgeting, are very important in a CDS. 


\section{- Governance}

Governance has a key role in CDS, because the local government has a close relationship with the main decision makers and can play the role of a catalyst between the public and private sectors, and civil society and the labour market. It can decrease the negative effects on low-income and vulnerable people (Cities Alliance 2006b).

\section{DISCUSSION: THE INCLUSION OF SUD PRINCIPLES IN CDS THEMES}

A survey done by Saha \& Petarson (2008) has been used as a basic framework to evaluate local governments' and cities' plans for sustainable development. These activities have been used to evaluate CDS as a strategic plan to move toward sustainability.

Based on the definitions and concepts of CDS reviewed in section 4.1 and sustainable urban development as described in Section 3, this section discusses how much CDS themes cover principles of sustainable urban development. This helps to identify the effect and role of CDS in sustainable urbanization. Table 3 presents the inclusion of SUD principles and activities in CDS themes. It shows each of Livelihood, Environmental sustainability, Spatial form and its infrastructure, Financial resources, and Governance elements (According to Table 2) how much can cover and fulfill the principles and activities of SUD. Each sustainable urban development activity has been cross-checked with the CDS themes, and the result is indicated in the Table3. Each of the CDS themes is discussed in relation to the sustainable urban development proposed by Saha \& Petarson (2008).

\section{Environmental protection}

Saha \& Paterson define fourteen activities on this subject and classify them in five categories. A comparison of CDS themes and these activities show that eleven of the fourteen activities are taken into account by CDS themes. Five activities of this aspect of sustainable urban development are covered by the environmental sustainability theme of CDS, five activities are covered by the spatial form and its infrastructure and one activity is covered by the livelihood theme. Thus, the CDS themes can address environmental aspect of sustainability well because the most activities of SUD are included by CDS themes.

\section{Economic development}

On economic development, eleven activities have been planned, ten of which are covered by CDS themes. Thus, CDS themes on livelihood, environmental sustainability, spatial form and its infrastructure and finance take into consider most of the necessary 
activities to achieve sustainable urban development. Therefore, economic sustainability will be the result of this definition of CDS.

\section{Social equity}

Also, eight activities of the social equity aspect of sustainable urban development are employed by the CDS themes. However, CDS themes do not adequately address minority and special groups, like women and youth. So, we can conclude that social sustainability has a lower position in this definition of CDS.

\section{Governance}

Governance aspect activities are completely covered by CDS themes. This is due to the fact that one of the stress points of CDS is governance. So CDS themes take into account all activities that concern this aspect.

This comparison shows that the CDS, in accordance with the definition that we have selected, can cover sustainable urbanization well. In the themes of CDS, we can find elements that can fulfill the principles of sustainable urbanization. Nonetheless, this study has been made according to the CDS guideline that was prepared by Cities Alliance in order to establish proper CDS in developing countries. In other words, this analysis relies on the themes that should be considered when a CDS is prepared. Therefore, it is possible that some CDS cannot achieve sustainable urbanization because they have not given careful attention to the CDS themes.

\section{CONCLUSION}

This paper has discussed CDS and their contribution and roles played in urban sustainable development. Sustainability in cities can be achieved through sustainable urban development and urban planning. Many researchers reviewed many concepts and activities in order to achieve sustainable urbanization. On the other hand, CDSs especially in developing countries have been developed with the objective of establishing space in order to reduce poverty, enhancing economic aspects, improving the environment, and promoting quality of life. However, CDS has different definitions for different cities and has been established based on different themes. Therefore for studying the contribution of CDS toward SUD, the definition of Cities Alliance in its guideline (2006b) has been selected. Until 2009, Cities Alliance has funded about 200 CDSs in developing countries. The definition of Cities Alliance that has been selected for this paper can be considered as a significant case study for developing countries. The inclusion of activities and principles of urban sustainable development were 
probed to CDS themes and detailed elements of every theme. This paper concludes that the CDS themes can fulfill some aspects of sustainable urbanization because this approach can cover many principles and activities of these aspects of SUD; however it is feeble to address some ones like social sustainability. It shows that the majority of sustainable urbanization aspects are covered in the development of a sustainable city in developing countries by using CDS.

\section{REFERENCES}

Abu-Ghazalah, Samer. 2008. The Sustainable City Development Plan for Aqaba, Jordan. Journal of Developing Societies 24:381-398.

Cities Alliance. 2002. Annual Report. Washington D.C.

Cities Alliance. 2006a. 2006 Annual Report.

Cities Alliance. 2006b. Guide to City Development Strategies: Improving Urban Performance Washington D.C.: The Cities Alliance.

Cities Alliance. 2007. Annual Report. Washington D.C.

Cities Alliance. 2009. 2009 Annual Report.

Conroy, Maria Manta. 2006. Moving the middle ahead: Challenges and opportunities of sustainability in Indiana, Kentucky, and Ohio. Journal of Planning Education and Research 26:18-27.

Diamantine, Corrado, and Bruno Zanon. 2000. Planning the urban sustainable development The case of the plan for the province of Trento, Italy. Environmental Impact Assessment Review 20:299-310.

Jepson, Edward J. 2004. The Adoption of Sustainable Development Policies and Techniques in U.S. Cities : How Wide, How Deep,and What Role for Planners? Journal of Planning Education and Research 23 (2):229-241.

Keivani, Ramin. 2009. A review of the main challenges to urban sustainability. International Journal of Urban Sustainable Development 1:15-16.

Kim, Kyung-Hwan. 2002. China CDS Performance Indicators: Final Report: UNHabitat Fukuoka Office.

Malkina-Pykh, Irina G. 2002. Integrated assessment models and response function models: pros and cons for sustainable development indices design. Ecological Indicators 2:93-108.

Mukhija, Vinit. 2006. Viewpoint Challenges for international development planning: Preliminary lessons from the case of the Cities Alliance. Cities 23:56-62.

Porter, Micheal. 1995. The competitive advantage of the inner city. Harvard Business Review 73:55-71.

Portney, Kent E. 2003. Taking sustainable cities seriously: Economic development, the environment, and quality of life in American cities. Cambridge: MIT Press. 
Rotmansa, Jan, Marjolein van Asselt, and Pier Vellinga. 2000. An integrated planning tool for sustainable cities. Environmental Impact Assessment Review 20:265-276.

Roy, Manoj. 2009. Planning for sustainable urbanization in fast growing cities: Mitigation and adaptation issues addressed in Dhaka, Bangladesh. Habitat International 33:276-286.

Saha, Devashree, and Robert G. Paterson. 2008. Local Government Efforts to Promote the "Three Es" of Sustainable Development Survey in Medium to Large Cities in the United States. Journal of Planning Education and Research 28:21-37.

Shen, Li-Yin, J. Jorge Ochoa, Mona N. Shah, and Xiaoling Zhang. 2011. The application of urban sustainability indicators - A comparison between various practices. Habitat International 35 (1):17-29.

Spangenberg, Joachim H., Stefanie Pfahl, and Kerstin Deller. 2002. Towards indicators for institutional sustainability: lessons from an analysis of Agenda 21. Ecological Indicators 2:61-77.

Tonami, Aki, and Akihisa Mori. 2007. Sustainable Development in Thailand Lessons From Implementing Local Agenda 21 in Three Cities. The Journal of Environment Development 16:269-289.

UN-Habitat. 2002. Local Democracy and Decentralization in East and Southern Africa: Experiences from Uganda, Kenya, Botswana, Tanzania and Ethiopia. Nairobi: UN-Hanitat.

UN-Habitat. 2009. Global Report on Human Settlements 2009: Planning Sustainable Cities London: Earth scan.

Whitehead, Mark. 2003. (Re) Analyzing the Sustainable City: Nature, Urbanization and the Regulation of Socio-environmental Relations in the UK. Urban Studies 40:1183-1206. 
Table 1 : $\quad$ Sustainable Urban development Principles and Activities

\section{Environmental Protection}

A. Energy Efficiency Measures

1. Alternative energy offered to consumers

2. Energy conservation efforts (other than green building requirements)

3. Environmental site design regulations

4. Green building program

5. Renewable energy use by the city government

B. Pollution Prevention and Reduction Measures

6. Curbside recycling program

7. Environmental education programs for the community

8. Green procurement

9. Water quality protection

C. Open Space and Natural Resource Protection Measures

10. Environmentally sensitive area protection

11. Open space preservation program

D. Transportation Planning Measures

12. Operation of inner-city public transit (buses and/or trains)

13. Transportation demand management

E. Tracking Progress on Protecting the Environment

14. Ecological footprint analysis

\section{Economic Development}

A. Smart Growth Measures

1. Agricultural protection zoning

2. Brownfield reclamation

3. Cluster or targeted economic development

4. Eco-industrial park development

5. Infill development

6. Purchase of development rights and/or transfer of development rights

7. Tax incentives for environmentally friendly development

8. Urban growth boundary and/or urban service boundary

B. Measures Promoting Local Employment/Industries

9. Business retention programs

10. Empowerment/enterprise zones

11. Local business incubator programs

\section{Social Equity}

1. Affordable housing provisions

2. Daycare services for the service sector and low-income employees 
3. Homeless prevention and intervention programs

4. Inclusionary and incentive zoning

5. Jobs-housing balance

6. Living wage ordinance

7. Mass transit access with local income subsidies

8. Neighborhood planning

9. Sustainable food systems or food security programs

10. Women/minority-oriented business community development corporations (CDCs) and investment programs

11. Youth opportunity and anti gang programs

\section{Governance}

1. Dispute resolution

2. Public participation

3. Regional coordination

Source: Saha \& Paterson (2008)

Table 2: The elements of CDS Themes based on Cities Alliance (2006)

\section{Livelihood}

\section{A. Business Climate}

1. Incentives Offered by the Local Jurisdiction

2. Nuisance Taxation

3. Ease of Starting a Business

4. Investment Approval Processes for Foreign Firms and Joint Ventures

5. Operating Environment of Informal Sector

6. Government Attitudes towards the Informal Sector

\section{B. Competitiveness}

1. Basic Economic Trends

2. Diversity versus Specialization

3. National and World-class Economic Activities

4. Productivity Gains

5. Economic Mix and Change

6. Movement up the Value Chain and Cluster Deepening

7. Rate of Start-ups and Business Deaths

8. Foreign Direct Investment

9. Innovation

10. Performance of Anchor Firms

11. Labor Market Efficiency

12. Marketing and Promotion

13. Attracting Talent 


\section{Human Resource Development}

1. Educational quality and quantity (enrolment at various levels).

2. Education-Economic Alignment

3. Access to Education

4. Financial Support to Students

5. Access to Entry-level Jobs

6. Geographic Accessibility to Labor Market

\section{Environmental Sustainability}

\section{A. Environmental Quality}

1. Air Pollution

2. Wastewater and Water Quality

3. Pollution Sources

4. Sustainability and Safety of Water Supply

5. Loss of Agricultural and Environmentally Sensitive Land

6. Amenity

7. Natural Hazards

B. Service Delivery and Policy Frameworks

1. Demand for Services

2. Delivery of Basic Needs

3. Health, Education, and Literacy Status

4. Quality of Basic Services

5. Delivery of Services to Migrants

6. Public Health

7. Efficiency in Delivery of

8. Maintenance

9. Energy and Environmental Policy Frameworks

C. Energy Efficiency

1. Energy Consumption

2. Urban Form and Energy Consumption

3. Demand Management

\section{Spatial Form and its Infrastructure}

\section{A. Infrasructure}

1. Infrastructure Delivery Performance

2. Infrastructure Delivery Modes

3. Planned Infrastructure

4. Trunk Infrastructure and Urban Form

5. Housing Supply and Demand

6. Affordable Land and Housing

7. Transportation Networks

8. Public Transportation Facilities and Services 
9. Urban Nodes and Public Transport Demand

10. Major Transportation Facilities

11. Movement of Goods

12. Telecommunication Services

B. Spatial Form

1. Formal and Informal Spaces

2. Urban Density

3. Land and Property Value Gradients

4. Land and Housing Markets

5. Monocentric versus Multinodal Form

6. Peri-urban Spatial Form

7. Location of the Service Economy

8. Spatial Distribution of Employment and Economic Output

9. Social Geography

10. Geography of Poverty

11. Location of Slums and Squatter Areas

12. Land Readjustment

13. Destination of Migrants

14. Geography of Investment

15. Congestion.

16. The Knowledge Economy

17. Expansion Vectors

18. Street Life, Entertainment, and Recreation

\section{Financial resource}

A. Local Government Financial Resources and Institutional Structures

1. Local Government Budgets

2. Local Government Revenues and Expenditures

3. Capital Planning

4. Off-budget Revenue and Expenditures

5. Transfers

6. Extent and Impacts of Decentralisation

7. Debt

8. Access to Credit

9. Credit Rating

10. Autonomous Bodies

B. Mobilizing Nongovernmental Capital

1. Impact of Land Readjustment

2. Impact of Land Tenure

3. Housing Credit

4. Financing Local Infrastructure 


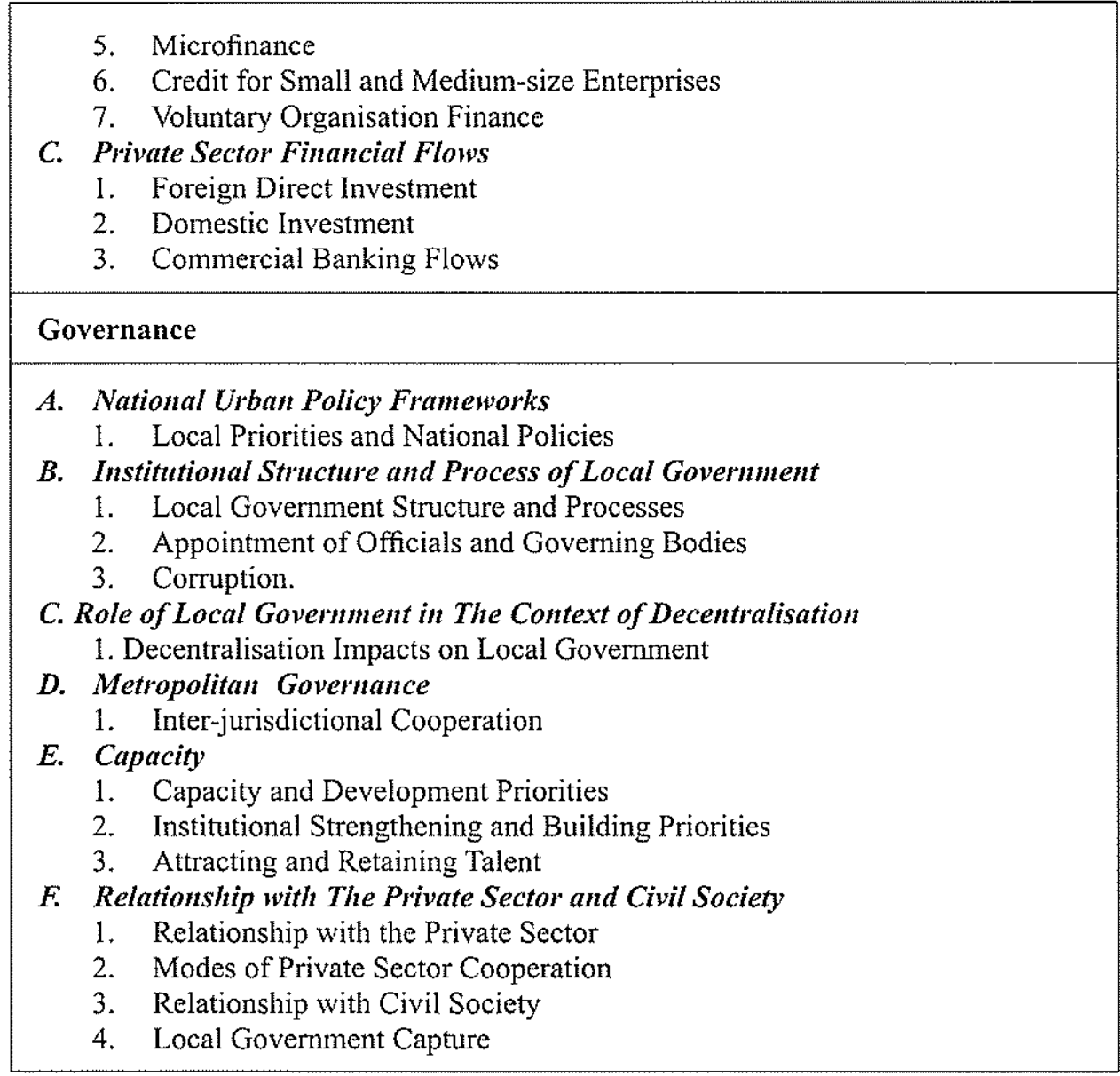

Source: Cities Alliance (2006b) 
Table 3 : Inclusion of SUD Principles and Activities in CDS Themes

\begin{tabular}{|c|c|c|c|c|c|}
\hline \multirow{2}{*}{$\begin{array}{l}\text { The sustainable urban } \\
\text { Development aspects }\end{array}$} & \multicolumn{5}{|c|}{ CDS Themes } \\
\hline & Livelihood & $\begin{array}{c}\text { Environmental } \\
\text { Sustainability }\end{array}$ & $\begin{array}{c}\text { Spatial } \\
\text { form }\end{array}$ & $\begin{array}{l}\text { Finance } \\
\text { Resource }\end{array}$ & Governance \\
\hline Environmental Protection & & & & & \\
\hline A. EnergyEfficiencyMeasures & & & & & \\
\hline $\begin{array}{l}\text { 1. Altemative energy offered } \\
\text { to consumers }\end{array}$ & - & $\checkmark$ & - & - & - \\
\hline 2. Energy conservation effort & - & $\checkmark$ & - & - & - \\
\hline $\begin{array}{l}\text { 3. Environmental site design } \\
\text { regulations }\end{array}$ & - & - & $\checkmark$ & - & - \\
\hline 4. Green building program & - & - & - & - & - \\
\hline $\begin{array}{l}\text { 5. Renewable energy use by } \\
\text { city government }\end{array}$ & - & $\checkmark$ & - & - & - \\
\hline $\begin{array}{l}\text { B. Pollution Prevention and } \\
\text { Reduction }\end{array}$ & & & & & \\
\hline $\begin{array}{l}\text { 6. Curbside recycling } \\
\text { program }\end{array}$ & - & - & - & - & - \\
\hline $\begin{array}{l}\text { 7. Environmental education } \\
\text { programs for the community }\end{array}$ & $\checkmark$ & - & - & - & - \\
\hline 8. Green procurement & - & - & - & - & - \\
\hline $\begin{array}{l}\text { 9. Water quality protection } \\
\text { C. Open Space and Natural } \\
\text { Resource Protection }\end{array}$ & - & $\checkmark$ & - & - & - \\
\hline $\begin{array}{l}\text { 10. Environ mentally } \\
\text { sensitive area protection }\end{array}$ & - & $\checkmark$ & - & - & - \\
\hline $\begin{array}{l}\text { 11. Open space preservation } \\
\text { program }\end{array}$ & - & - & $\checkmark$ & - & - \\
\hline $\begin{array}{l}\text { D. Transportation Planning } \\
\text { Measures }\end{array}$ & & & & & \\
\hline $\begin{array}{l}\text { 12. Operation of inner-city } \\
\text { public transit }\end{array}$ & - & - & $\checkmark$ & - & - \\
\hline $\begin{array}{l}\text { 13. Transportation demand } \\
\text { management }\end{array}$ & - & - & $\checkmark$ & - & - \\
\hline $\begin{array}{l}\text { E. Tracking Progress on } \\
\text { Protecting the Environment }\end{array}$ & & & & & \\
\hline $\begin{array}{l}\text { 14. Ecological footprint } \\
\text { analysis }\end{array}$ & - & - & $\checkmark$ & - & - \\
\hline
\end{tabular}




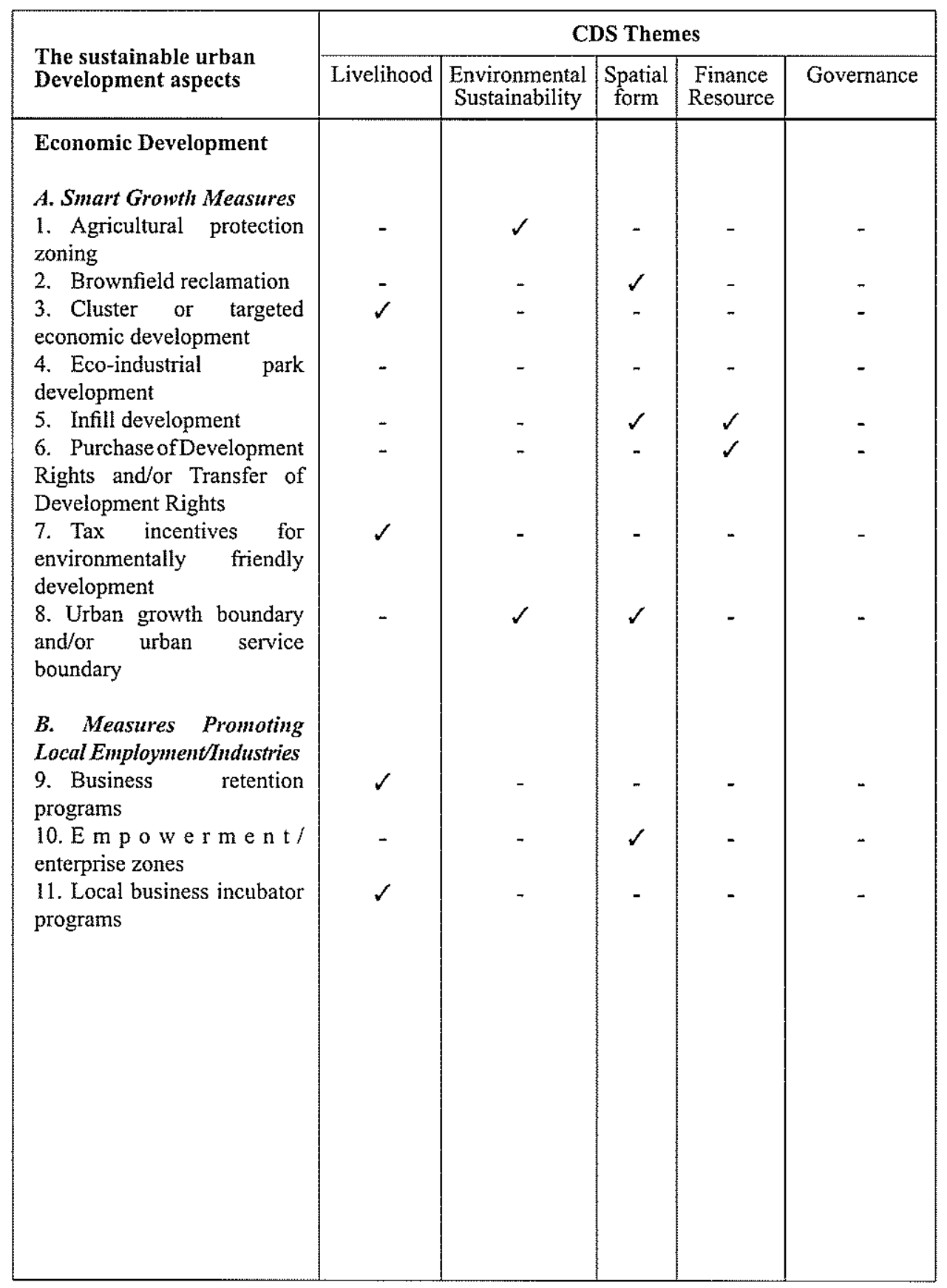

